\title{
Pemantapan Wawasan Nusantara untuk Penguatan Ketahan Nasional
}

\author{
Alfara Derista Felany \\ Institut Ilmu Kesehatan Strada Indonesia \\ alfaraderista05@gmail.com
}

\begin{abstract}
Abstrak
Wawasan nusantara adalah cara pandang bangsa Indonesia terhadap lingkungan sekitarnya. Dalam mewujudkan kepulauan nusantara sebagai satu kesatuan politik, sosial budaya, ekonomi, pertahanan dan keamanan. Wawasan Nusantara bangsa Indonesia merupakan penjabaran dari falsafah, pandangan hidup, ideologi Bangsa Indonesia yaitu Pancasila yang didasari oleh pengalaman sejarah, kondisi geografi, sosial budaya bangsa Indonesia. Wawasan kebangsaan, yang nilai-nilainya bersumber dari ideologi Pancasila, harus menjadi suatu kesadaran bagi seluruh komponen bangsa, dari rakyat sampai para pejabat atau pimpinan negara dan masyarakat. Diharapkan melalui kesadaran wawasan kebangsaan ini pengelolaan tata kehidupan berbangsa dan bernegara akan menjadikan bangsa ini menjadi bangsa yang besar, solid, bersatu dan semua kepentingan rakyat, bangsa dan negara terakomodasikan. Sehingga bangsa Indonesia ke depan mampu bersaing dengan bangsalain dan mampu mengeliminasi berbagai pengaruh negatif nilainilai kehidupan global, baik saat ini maupun yang akan datang.
\end{abstract}

\section{Latar Belakang}

Rakyat suatu bangsa dalam membina dan menyelenggarakan tata hidup bangsa dan negara yang meliputi baik tata negara (sistem pembinaan negara dan Bangsa), maupun tata budaya (sistem pembinaan budi pekerti masyarakat bangsa), ataupun tata hukum (sistem pembinaan hukum dan perundang-undangan), sebenarnya merupakan cerminan dari Wawasan Nasionalnya. Pengkajian dan pembahasan tersebut kemudian menunjukkan bahwa untuk dapat menyelenggarakan dan meningkatkan serta menjamin kelangsungan hidup bangsa Indonesia memerlukan konsepsi Nasional yang merupakan tentang wawasan nasionalnya. Yang selanjutnya akan menjadi landasan dan pedoman kebijakan nasional di segala segi kehidupan.

Dalam usaha mencapai tujuan nasional, masih banyak yang memiliki pandangan berbeda. Untuk itu pemerintah telah merumuskan pandangan nasional yang komperhensif dan integral yang dikenal dengan wawasan nusantara. Wawasan ini akan memberikan konsepsi yang sama kepada peserta didik tentang visi ke depan bangsa Indonesia untuk menciptakan kesatuan dan persatuan secara utuh, sehingga dapat mewujudkan integrasi nasional. Adanya nilai-nilai nasionalisme, khususnya nilai kesatuan, sangat mendukung terwujudnya integrasi nasional. Dengan demikian nilai-nilai wawasan nusantara, kususnya nilai kesatuan, yaitu kesatuan IPOLEKSOSBUD-HANKAM sangat mendukung adanya integrasi nasional. 
Dengan demikian, wawasan nasional adalah cara pandang suatu bangsa yang telah menegara tentang diri dan lingkungannya dalam eksistensinya yang serba terhubung (melalui interaksi dan interrelasi) dan dalam pembangunannyadi lingkungan nasional (termasuk local dan propinsional), regional serta global.

Unsur dasar wawasan nusantara ada tiga yaitu wadah, isi, dan tata laku. Wadah (content) bermakna bahwa wawasan nusantara merupakan wadah kehidupan bermasyarakat, berbangsa dan bernegara meliputi seluruh wilayah Indonesia yang memiliki sifat serba nusantara dengan kekayaan alam dan penduduk serta aneka ragam budaya. Sementara itu, isi (content) menandakan bahwa wawasan nusantara adalah aspirasi bangsa yang berkembang di masyarakat dan cita-cita serta tujuan nasional yang terdapat dalam Pembukaan UUD 1945. Selanjutnya, hasil interaksi antara wadah dan isi yang disebut dengan tata laku (conduct) terdiri dari dua tata laku yaitu tata laku bathiniah dan tata laku lahiriyah. Tata laku Bathiniah mencerminkan jiwa, semangat dan mentalitas yang baik dari bangsa Indonesia sedangkan Tata laku Lahiriah tercermin dalam tindakan, perbuatan dan perilaku dari bangsa Indonesia. Kedua tata laku tersebut mencerminkan identitas jati diri/kepribadian bangsa berdasarkan kekeluargaan dan kebersamaan yang memiliki rasa bangga dan cinta terhadap bangsa dan tanah air sehingga menimbulkan rasa nasionalisme yang tinggi dalam semua aspek kehidupan nasiona

Dalam pembentukannya, wawasan nusantara terdiri dari beberapa asas. Asas yang pertama yaitu kepentingan yang sama. Kepentingan yang sama memiliki makna bahwa warga negara Indonesia harus memiliki satu visi dan satu orientasi dalam memahami wawasan nusantara ini. Asas yang kedua adalah keadilan yang bermakna distribusi sumber daya dan hasil yang proporsional. Asas selanjutnya adalah yang memiliki makna bahwa terdapat kesesuaian antara kata dengan tindakan. Asas yang ke empat adalah solidaritas yang bermaksud bahwa seluruh elemen negara dapat saling berempati dan bersimpati dalam rangka menjaga kesatuan dan persatuan negara Indonesia. Asas yang ke lima adalah kerjasama yang memiliki definisi untuk harus bekerjasama secara strategis maupun taktis untuk mencapai tujuan bersama yaitu tujuan nasional. Asas yang terakhir adalah kesetiaan yang memiliki makna arti sebagai loyalitas dari warga negara dan unsur-unsur negara terhadap kesepakatan-kesepakatan nasional yang telah dibuat semenjak bangsa Indonesia berdiri. Jika enam asas tersebut tidak dijalankan dengan baik, maka akan sangat sulit untuk mencapai tujuan akhir dari wawasan nusantara ini, yaitu perwujudan nilai-nilai Pancasila dan UUD 1945

Dalam rangka mewujudkan wawasan kebangsaan ini, maka berbagai langkah kebijakan yang perlu diambil antara lain: Saat ini kegiatan pemantapan wawasan kebangsaan telah dilakukan oleh berbagai instansi pemerintah (17 lembaga) namun dengan kurikulum, materi dan metode pengajaran yang berbeda-beda, serta belum terstruktur dan berkesinambungan, sehingga pemantapan wawasan kebangsaan bersifat sektoral dan partial dan bahkan seringkali terjadi perbedaan dan salah tafsir bagi para peserta didik. Oleh karena itu diperlukan suatu "Grand Desain Wawasan Kebangsaan" yang akan menjadi panduan dan pedoman bagi seluruh komponen bangsa dalam rangka melaksanakan kegiatan pemantapan wawasan kebangsaan. Grand Desain Wawasan Kebangsaan ini diatur dalam suatu kebijakan politik (regulasi) yang mempunyai kekuatan hukum yang mengikat bagi seluruh kelembagaan negara dan seluruh komponen masyarakat. Wawasan nusantara memiliki peranan penting untuk mewujudkan persepsi yang sama bagi seluruh warga negara Indonesia. Dengan persepsi yang sama diharapkan dapat membawa bangsa menuju kesepahaman dan kesehatian dalam mewujudkan cita-cita nasional. 


\section{Rumusan Masalah}

1. Apa pengertian dari wawasan nusantara?

2. Apa tujuan dari penanaman wawasan nusantara?

3. Bagaimana cara untuk melakukan pemantapan terhadap wawasan nusantara?

\section{Tinjauan Pustaka}

Menurut Hasnan Habib wawasan nusantara adalah kebulatan wilayah nasional, termasuk satu kesatuan bangsa, satu tujuan dan tekad perjuangan dan satu kesatuan hukum, satu kesatuan sosial budaya, satu kesatuan ekonomi dan satu kesatuan hankam.

Menurut Prof. DR. Wan Usman bahwa wawasan nusantara adalah cara pandang Bangsa Indonesia mengenai diri dan tanah airnya sebagai negara kepulauan dengan semua aspek kehidupan yang beragam. Selain itu wawasan nusantara sebagai wawasan nasional Bangsa Indonesia harus sesuai dengan filsafat hidup bangsa serta kondisi geografis dan sosial budaya Bangsa Indonesia.

Menurut Sumarsono menjelaskan bahwa wawasan nusantara adalah nilai yang menjiwai segenap peraturan perundang-undangan yang berlaku pada setiap strata di seluruh wilayah negara, sehingga menggambarkan sikap dan perilaku, paham serta semangat kebangsaan atau nasionalisme yang tinggi yang merupakan identitas atau jati diri Bangsa Indonesia.

\section{Pembahasan}

Secara etimologi wawasan nusantara terdiri dari dua kata yaitu wawasan dan nusantara. Wawasan merupakan kata kerja yang berasal dari bahasa jawa. Wawas mengandung arti melihat, memandang. Wawasan berarti pandangan, tinjauan, penglihatan, tanggap indrawi. Jadi, wawasan adalan cara pandang seseorang atau bangsa, sebagai salah satu aspek dari falsafah hidup. Berisi dorongan-dorongan dan rangsangan-rangsangan agar dapat mewujudkan aspirasi, keinginan dan kebutuhan dalam mecapai tujuan hidup. Makna wawasan juga sebagai pantulan (refleksi) dan pancaran dari falsafah hidup, yang berisi asas-asas, metode dan isi cita cita.

Nusantara berasal dari dua kata yakni nusa berarti pulau. Berupa pulau-pulau yang terletak diantara dua benua (Asia dan Australia) serta dua samudera (Pasifik dan Hindia). Kemudian kata antara diartikan sebagai tanah air Indonesia, yaitu kesatuan wilayah perairan dan gugusan pulau-pulau yang terletak diantara dua samudera Pasifik dan Hindia atau Indonesia dan dua benua Asia dan Australia.

Wawasan Nusantara diartikan sebagai cara pandang bangsa Indonesia tentang diridan lingkungan berdasarkan ide nasionalnya, yang dilandasi Pancasila dan Undang-Undang Dasar 1945, yang merupakan aspirasi bangsa Indonesia yang merdeka, berdaulat dan bermartabat serta menjiwai tata hidup dan tindak kebijakannya dalam mecapai tujuan perjuangan nasional. 
Dengan demikian Wawasan Nusantara dapat diartikan sebagai cara pandang bangsa Indonesia tentang diri dan lingkungannya berdasarkan ide nasionalnya yang dilandasi Pancasila dan UUD 1945, yang merupakan aspirasi bangsa merdeka, berdaulat, bermartabat, serta menjiwai tata hidup dan tindak kebijaksanaannya dalam mencapai tujuan nasional. Wawasan Nusantara adalah cara pandang, cara memahami, cara menghayati, cara bersikap, cara berfikir, cara bertindak, cara bertingkah laku, bangsa Indonesia sebagai interaksi prosees psikologis, sosiokultural, dengan aspek ASTAGATRA (Kondisi geografis, kekayaan alam dan kemampuan penduduk serta IPOLEKSOSBUD Hankam).

Penanaman dan pengembangan wawasan kebangsaan harus dilakukan mulai sejak pendidikan dini sampai pendidikan tinggi dan dilaksanakan sebagai pendidikan sepanjang hidup (long life education). Oleh karena itu wawasan kebangsaan harus menjadi materi pelajaran yang termuat dalam kurikulum pelajaran untuk Pendidikan Tingkat Dasar (SD), Pendidikan Tingkat Lanjutan (SLTP dan SLTA), serta Perguruan Tinggi.

Pemantapan nilai-nilai kebangsaan juga wajib ditanamkan kembali kepada para pelaku usaha atau ekonomi nasional, mencakup kalangan pengusaha swasta besar-menengah-kecil, badan usaha milik Negara dan koperasi. Pemantapan nilai-nilai kebangsaan juga wajib dilakukan kepada generasi muda, baik yang tergabung dalam organisasi-organisasi kepemudaan maupun yang tergabung melalui kegiatan pembinaan generasi muda seperti pramuka, badan eksekutif mahasiswa, korps Menwa dsbnya.

\section{Kesimpulan}

Wawasan Nusantara memiliki peranan penting untuk mewujudkan persepsi yang sama bagi seluruh warga negara Indonesia. Perbedaan persepsi, perbedaan pendapat, dan freksi-freksi antar kelompok dalam konteks sosologis, politis serta demokrasi dianggap hal yang wajar dan sah-sah saja. Hal di atas justru diharapkan dapat menghasilkan masyarakat yang dinamis dan kreatif, sinergis, untuk saling menyesuaikan menuju integrasi. Suatu pantangan yang harus dihindari adalah perbuatan, tindakan yang melanggar norma-norma etika, moral, nilai agama atau tindakan anarkis menuju ke arah disintegrasi bangsa. Namun demikian wawasan normatif, wawasan yang disepakati bersama perlu dimengerti, dipahami di sosialisasikan bahwa Nusantara sebagai kesatuan kewilayahan, kesatuan IPOLEKSOSBUDHANKAM tidak dapat ditawar lagi, tidak dapat diganggu gugat sebagai harga mati yang normatif.

Pembinaan dan sosialisasi Wawasan Nusantara sangat penting bagi negara bangsa karena dapat menghasilkan Ketahanan Nasional. Daya tahan yang kuat bagi sauatu bangsa dan kerja sama yang sinergis antar bidang (IPOLEKSOSBUD-HANKAM) yang diusahakan terus menurus dapat menghasilkan integrasi nasional yang utuh menyeluruh. 


\section{Daftar Pustaka}

Kusrahmadi, S. D. (2017). Pentingnya Wawasan Nusantara dan Integrasi Nasional.

Widjojo, A. (2016, June). Pemantapan Nilai-Nilai Ideologi Bangsa Dalam Rangka Penguatan Ketahanan Nasional Dalam Aras Global. In Seminar Nasional Hukum Universitas Negeri Semarang (Vol. 2, No. 1, pp. 7-18).

Nusantara, A. P. W. MODUL 6 WAWASAN NUSANTARA. PENDIDIKAN KEWARGANEGARAAN, 100.

Ilyasa, A. (2021, June). Wawasan Nusantara. In UNUSIA CONFERENCE (Vol. 1, No. 1, pp. 227-238).

Siyoto, S., \& Sodik, M. A. (2015). Dasar metodologi penelitian. Literasi Media Publishing. 